\title{
APPLICATION FOR FFPS MEMBERSHIP
}

\section{Please complete in block letters}

Name

Title

Address

Membership categories (tick appropriate box)

Standard $£ 20 \square$ Family $£ 25 \square$ Concessionary (senior citizen, unwaged, student*) $\square £ 12$

Benefactor $£ 35 \square$ Associate (no Oryx) $£ 10 \square \quad$ Life $£ 1000 \square$

Airmail despatch (see inside cover for standard despatch details) $£ 7.50 \square$

*If student please give date you expect to finish studies

\section{METHODS OF PAYMENT}

\section{CHEQUE/ POSTAL OR MONEY ORDER/ GIRO CREDIT (Currency: $£$ sterling or US\$ only)}

I enclose

$£$

or equivalent \$US at current exchange rate)

\section{CREDIT CARD (AMERICAN EXPRESS OR VISA ONLY)}

Name of card

Name of card holder

Card No.

Expiry date

3. BANKER'S ORDER Please send to the FFPS, not to your bank.

Name

Account No.

Bank Sort Code

Name and address of bank

Please pay for the credit of Fauna and Flora Preservation Society, Account No. 60336130,

Barclays Bank plc (20-12-75), 139/142 North Street, Brighton BN1 1RU

my subscription of $£ \ldots \ldots \ldots \ldots \ldots$ due on

year until further notice.

and the same amount on the same day each

Signature

This cancels any previous order in favour of the FFPS.

\section{DEED OF COVENANT}

If you pay income tax in the UK you can greatly increase the value of your subscription to the FFPS, at no additional cost to yourself, by signing this Deed of Covenant.

I (full name)

of

hereby covenant with the Fauna and Flora Preservation Society, whose office is 1 Kensington Gore London SW7 2AR, that for a period of four years from the date hereof, or until my death (whichever shall be the shorter period) I will pay annually to the said Society from the day

of .................. (this date should be later that the date of the signature) in every year such a sum as, after deduction of income tax at the standard rate for the time being in force, amounts to $£ \quad \ldots \ldots \ldots \ldots \ldots . . . . .$. (please insert the actual amount of your subscription), such a sum to be paid from my general fund of taxed income.

Signed and sealed by me this Signature

* day of In the presence of 19

(signature of witness, who should not be your spouse)

Address

* The first payment must be received within 1 year from this date. 


\section{Wildlife Research}

Wildlife Research publishes original contributions to knowledge of the biology and management of wild vertebrates. Papers include studies of animal habitats, ecology, ecophysiology, nutrition, reproductive biology, behavioural ecology, population dynamics, modelling, reviews, descriptions and assessments of field and laboratory techniques, and technical notes. Technical notes describe techniques or instrumentation, without detailed assessment. All papers are refereed. The journal is published six times a year; there are no page charges. Contents pages are listed in Current Contents and papers are abstracted by all leading abstracting services.

\section{Editorial Advisory Committee}

Chairnan: D.M. Spratt, CSIRO Division of Wildlife and Ecology, Canberra.

Members: M. Bomford, Bureau of Rural Resources, Canberra; P.B. Copley, National

Parks and Wildlife Service, South Australia; H. Ford, University of New England, Armidale;

J.A. Friend, Department of Conservation and Land Management, Western Australia;

R. Shine, University of Sydney.

The Notice to Authors is published in the first issue of each volume. Copies are available on request. Send manuscripts to the Managing Editor, Wildlife Research, P.O. Box 89, East Melbourne, Vic. 3002, Australia.

Subscriptions for 1993: Australia and New Zealand \$A180; other countries \$US180. Subscriptions for 1994: Australia and New Zealand \$A195; other countries \$US195. Overseas subscribers receive their journals by air or economy air mail. Special personal rates are available through certain scientific societies in Australia and New Zealand.

Back issues $\$ 40$.

\section{Order Form}

I wish to subscribe to Wildlife Research $1993 \square \quad 1994 \square$

I enclose a cheque/money order payable to CSIRO for $\$$

Name

Address

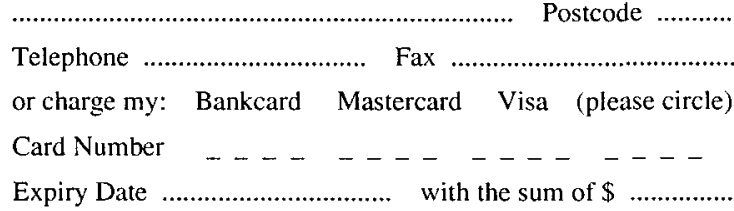

Signature

Send your order to: CSIRO Publications, P.O. Box 89, East Melbourne, Vic. 3002, Australia. Telephone: (03) 4187231 . Fax: (03) 4190459. International enquiries: telephone (613) 4187231 or fax (613) 4190459. 


\section{ORYX: NOTES FOR CONTRIBUTORS}

General Oryx publishes original articles and reports dealing with the conservation of species and habitats world-wide, with particular emphasis on those that are endangered. All submissions are reviewed by at least two referees. It is helpful if authors suggest at least one referee who is qualified to judge the work objectively.

Submissions should be sent to the Editor, FFPS, 1 Kensington Gore, London SW7 2AR.

After acceptance papers may be edited to enhance clarity. Where major changes have been made edited manuscripts are returned to authors before type-setting. Page proofs are sent to all authors for approval before going to press. Contributors receive two free copies of the journal and will be entitled to buy additional copies at $£ 2.00$ each, post free. Offprints may be ordered at cost price.

Contributions should be concise but informative, normally in English. Articles should be as short as possible, preferably under 2500 words, and very short articles are acceptable.

Manuscripts should be typed on one side only and double-spaced on A4 paper $(208 \times 298$ $\mathrm{mm})$. The left-hand margin must be at least 40 $\mathrm{mm}$ wide. Two copies should be submitted and authors are also invited to submit papers on disk (IBM compatible or Apple format).

Footnotes should be avoided but, if necessary, should be indicated with asterisks in the text. The author's name and postal address should follow any acknowledgments and references at the end of the article.

References in the text should give the author's name with the year of publication in parentheses. The reference list should be in alphabetical order and include the full article title.

References should be given according to the abbreviations in the World List of Scientific Periodicals. Thus:
Aveling, C. and Harcourt, A.H. 1984. A census of the Virunga gorillas. Oryx, 18, 8-13.

Hartshorn, M.G. 1983. Wildlife conservation in Central America. In: Tropical Rain Forest: Ecology and Management (eds S. L. Sutton, T. C. Whitmore and A. C. Chadwick), pp. 421-423. Blackwell Scientific Publications, Oxford.

Illustrations are welcomed and ideally should be glossy, black-and-white whole-plate prints. Good colour slides are acceptable if black-andwhite photographs are not available.

Line drawings and maps should be in black ink on strong white or translucent paper. Lettering on maps and figures should be sent on a separate copy of the figure along with the unlabelled original.

Captions for figures should be typed consecutively on a separate sheet.

Tables. Each table should be self-explanatory and typed on a separate sheet with an appropriate caption.

Scientific names should be underlined and not placed in parentheses. Species' names should follow a checklist, which should be mentioned in a covering letter where there is a risk of confusion.

The first time a species is mentioned its scientific name should be given. English names should be in lower case throughout except where they incorporate a proper name.

Paper. The publisher's policy is to use acidfree permanent paper, to the draft standard ISO/DIS 9706, made from sustainable forests using chlorine-free pulp. The paper used in this journal has an ECO-CHECK 4-star rating. 


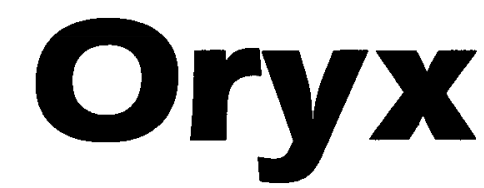

Contents Editorial 1

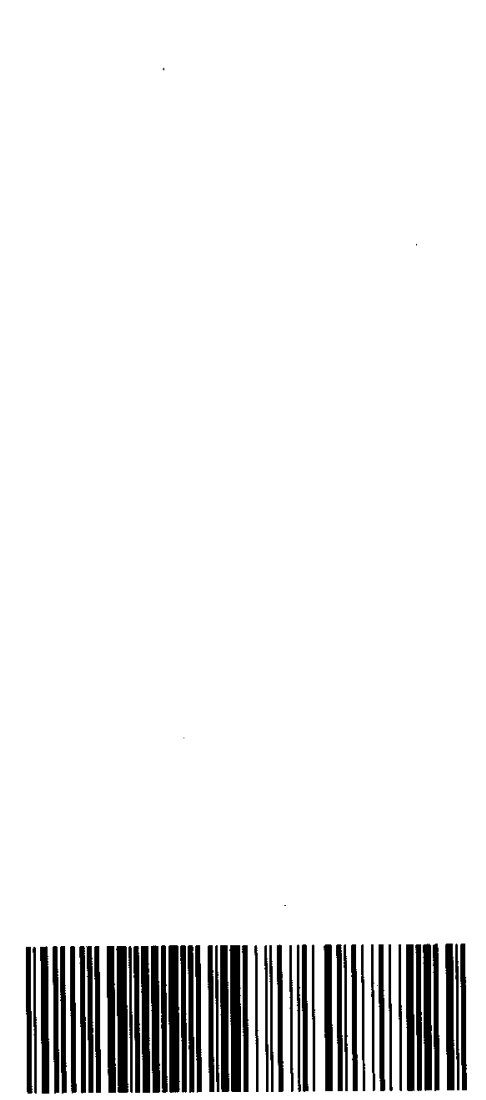

$0030-6053(199401) 28: 1: 1-I$

Cover

Shallow reef in the Red Sea (Carl Roessler/Bruce Coleman Ltd).

Briefly 4 Vietnam

Goura Brazil prognosis

India
Volume 28 Number 1 January 1994

News and Views 2

Discovery and conservation of the Vu Quang ox in

Vu Van Dung, Pham Mong Giao, Nguyen Ngoc Chinh, Do

Tuoc and John MacKinnon 16

Conservation considerations for crowned pigeons, genus

Catherine E. King and Joeke Nijboer 22

Two new Brazilian primates discovered, endangered Stephen F. Ferrari and Helder L. Queiroz 31

Conservation of the brown howler monkey in south-east

Adriano Garcia Chiarello and Mauro Galetti 37

Pangolins in south-west Nigeria - current status and

Olufemi A. Sodeinde and Segun R. Adedipe 43

Sea turtles of Madagascar - their status, exploitation and conservation

Berthin Rakotonirina and Andrew Cooke 51

Status of the hog deer in Sri Lanka

Andrew J. McCarthy and Sarath B. Dissanayake

62

Short Communications

Rediscovery of the Bornean bay cat

Mel Sunquist, Charles Leh, Fiona Sunquist, Daphne M.

Hills, Rajanathan Rajaratnam 67

The decline of the wild water buffalo in north-east

Anwaruddin Choudhury 70

FFPS News $\mathbf{7 4}$

\section{Blackwell Scientific Publications}

FFPS

OXFORD LONDON EDINBURGH BOSTON

MELBOURNE PARIS BERLIN VIENNA

Typesetting and composition by J. Morris

Printed by Eyre and Spottiswoode, Margate 